\title{
Quran Education for Special Children: Teacher as Murabbi
}

\author{
Noornajihan Jaafar', Norakyairee Mohd Raus1, Nurul Asiah Fasehah Muhamad1, \\ Norzulaili Mohd. Ghazalid'1, Robiatul Adawiyah Mohd @ Amat' \\ Syed Najihuddin Syed Hassan', Mahyuddin Hashim¹, Ab. Halim Tamuri², \\ Norshidah Mohamed Salleh ${ }^{3}$, Mohd IsaHamzah ${ }^{3}$ \\ ${ }^{1}$ Faculty of Quranic and Sunnah Studies, Islamic Science Universitiy of Malaysia, Bandar Baru Nilai, Malaysia \\ ${ }^{2}$ International Islamic University College Selangor, Bandar Seri Putra, Malaysia \\ ${ }^{3}$ Faculty of Education, National University of Malaysia, Bandar Baru Bangi, Malaysia \\ Email: noornajihan@usim.edu.my
}

Received 26 January 2014; revised 26 February 2014; accepted 5 March 2014

Copyright (C) 2014 by authors and Scientific Research Publishing Inc.

This work is licensed under the Creative Commons Attribution International License (CC BY). http://creativecommons.org/licenses/by/4.0/

(c) (i) Open Access

\begin{abstract}
This paper discusses scenarios that occur in the delivery of the National Education Program, focusing the debate on the Special Education teacher professionalism especially teachers of Islamic Studies (IET). The objective of this study is to propose solutions to issues and challenges of the teaching profession by presenting a model of Special Education teacher as Murabbi. The term $\mathbf{M u}$ rabbi is selected in this model as opposed to Mursyid, Mu'allim, Muaddib, and Mudarris, because Murabbi encompasses the concept of love which is very close to special children as applied in this element. The findings of this study have resulted a model teacher as Murabbi particularly in the context of special education. There are eight characteristics of effective teachers as Murabbi contribute towards upholding the special education system of the country.
\end{abstract}

\section{Keywords}

Murabbi, Quran Education, Special Children

\section{Introduction}

Scenario of religious education among the disabled is seen as a critical issue whereby many factors have been identified as null and void that should be taken seriously by the various parties. Apart from policy issues, policies, awareness of parents with special children, community awareness and the relevant authorities, the issue of teacher trainers who are performers and educators in ensuring the sustainability of the agenda Rabbaniyyah Tar- 
biyyah is the main debate. This makes the task of teachers in general and Islamic education teacher (IET) in particular is becoming increasingly heavy (Ab. Halim Tamuri, 2011). Their role is not only as a presenter of the learning syllabus found in textbooks but as agents of moral educators of students. For this position of trust, teachers should act as second parents to the pupils in the school (Abidin Ibn Rusd, 1998) moreover it involves the transfer of knowledge and appreciation of the special children.

In the context of this study, teachers as Murabbi refer to the teaching profession through established Rabbani thought, maintained through quality, developed through knowledge and appreciation of the delivery process, and empowered through leadership and direction (Edy, 2009). In the context of educating the disabled, the term will see the priority aspects of teacher characteristics as Murabbi to celebrate the group's needs and privileges. In other words, the educational element (Tarbiyyah) can be understood as a process covering all aspects of human life such as spiritual, intellectual, emotional, physical and social and done in stages to keep, raise and educate individuals to attain to perfection, which is capable of role as the original purpose it was created, namely slaves and caliphs (al-Alusi, 2001).

Quran education in the context of this study refers to the transfer of knowledge based on the Quran with regard to strategies, approaches, methods and techniques of teaching and learning (T\&L) in accordance with a special child's ability level. Construction incorporates the contents of faith and morals, appreciation biography, and application specific syllabus of worship as well as its main basic teaching of the Quran. In other words, it is offering religious classes or the Quran studying which cannot be accessed and followed by special children through mainstream religion classes offered by JAKIM such as the Quran and the Fardhu Ain class (KAFA), or the Federal Department of Religious (JAWI) through Primary Religion School (SRA), and the State Islamic Religious Department (JAIN) through the People's Religious Schools (SAR) or the State Religious Schools (SAN). The essence of the term is consistent with the concept of education as highlighted by Ibn Qayyim in his Miftah Dar al-Sa'Adah book. He said educational concept comprises of three main elements which are the process of giving knowledge to teach human, nourishing the individual with the knowledge, and the process of educating hearts and souls.

Special children are referring to children with special needs that require attention and care that differs from typical children. Children differ in terms of the characteristics of neurological, sensory ability, the ability to communicate, behaviour and emotional and physical characteristics (Wan Sabri et al., 2013). In Malaysia, efforts to improve the ability of Special Needs Students (SNS), is pioneered by the Ministry of Education (MOE) through the Special Education Division (SED) including developing and providing educational services to those categorized as students who have vision problems, hearing problems and learning disabilities. By providing space and opportunity for SNS mainstream education has been realized in the National Special Education programme. However, space for religious education as offered in KAFA system, SAR, SAN and SRA are almost null. Based on the observations of the researchers, there are initiatives of IET and $j$-Qaf teachers in National Schools Special Education (NSSE) of Vision Problems in finding teachers of religion and the Quran, and raising their own funds, such as through the PTA to offer religion classes in the afternoon as implemented by a typical student religious class system in place. However, space for religious classes for Hearing Impairment and Learning SNS is practically not done.

Therefore, this study discusses the key elements that can be classified in the context of teacher as Murabbi through the perspective of the Qur'an education among the special children. Hopefully, this partnership can provide little impact and academic contribution to the teaching career, especially in the field of Islamic studies and authorities in support of religious and cultural rights of the realization of the Quran education classes for special children throughout the state.

\section{The Scenario of Teacher Development in Quran Education for Special Children}

The issues of none religion class offerings for children with special need as offered to the typical children through the KAFA classes and SAR/SRA/SAN—is like denying them the rights and beauty of religious life indirectly. For example, studies by Norakyairee Ab. Halim (2011) found that the absence of a specific class that aided the teaching of the Braille Quran in Islamic Education curriculum for the Visually Impaired SNS to some extent inhibited the process of learning the Quran. Teachers have to take their own initiative to hold an additional class where religious teachers are called upon to teach in the evening. In fact, it is even more concerning for hearing SNS (Mohd Huzairi, 2010) and learning disabilities (http://www.tutor.com.my, 2010), they do not 
have access to classes to learn the religion though its offerings through cooperation between the ministries concept involves Ministry of Education (MOE), Ministry of Health Malaysia (MOH) and the Social Welfare Department (SWD) has begun as early as the 1980's.

This void needs a call to change policy and plan through prudent strategies of authorities ranging from the MOE, JAKIM and JAIN. This aims to ensure that children are given special rights linking religious education for these special children with the creator (Ahmad, 2004; al-Ghazali, 1939; Mohd Huzairi, 2010).

According to the blog writer, teacher Sue who is also a Special Education teacher, there was a time the shortage of teachers in Special Education was overwhelming. The Department of Education had advertised openly for anyone interested in teaching Special Education classes. Unfortunately the response was very disappointing. If there are ever teachers sent to the Special Education class, they are teachers with problems in health or discipline, and teachers who are considered to be invaluable in the mainstream. Consequently it gives a negative outlook on the implementation of special education programme, as it is totally contrary to the requirements and needs of SNS (Source: Website e-Knowledge, http://cikgusuepkhas.blogspot.com).

According K. A. Razhiyah (2010), there are also some teachers who volunteer to teach special education classes but not because of interest as to flee from the mainstream workload. They assume in Special Education classes there are not many tasks to do. He added that the syndrome of going back to their hometown, there is no other option, and additional allowance are the reasons why some teachers drawn in this field. It is not surprising there is a request to return to mainstream schools as a teacher or transfer due to academic exchange.

Following the shortage of teachers, the Ministry of Education has opened an opportunity for untrained teachers in Postgraduate Teaching Course (KPLI). Special education began to accept train teachers who come from a variety of options. Some of the senior teachers feel quite relieved that the negative perception may change when the Special Education began to be taught by teachers with degrees. We do not deny that there are some teachers who are very committed but the number is very little when compared with various other problems that arise later. There are some who are not interested but had to teach well because there are no jobs, and some who cannot fully committed and failed to teach well is one of the major problem in Special Education. The period of time allotted to train them is not relevant to being a teacher even more special education teachers. Lack of knowledge and experience lead to the ineffective teaching and learning process and there are some who feel uncomfortable with SNS.

In addition, the failure of this group of graduate teachers to interact and establish good relations with the senior teachers and added with the syndrome of not wanting to learn or ask causing negative effect to the teaching process. This is because they are clearly lacking teaching skills and knowledge. They made less success in application of strategies, approaches, methods, techniques, and evaluation necessary to the needs of SNS. They are also quick to give up, quick temper and weary on SNS. They would rather occupy themselves with other tasks such as co-curriculum, attend courses, and so on.

Some teachers consider special education teachers have the easiest work. They do not have to check the abundant question papers, or think of a strategy to ensure students academic excellence, plus they have only a few students in the classroom. Perhaps it's a correct guess if the teachers take for granted what will be taught to students in special education, but it is not easy if the teachers really want to teach the students knowledge and accept something when they come to school every day. Thus, all the important tasks are entrusted to the Special Education teacher. The busy and irrelevant workload causing concern over students and Special Education classes neglected and abandoned (Source: Website e-Knowledge, http://cikgusuepkhas.blogspot.com).

In the context of the teachers' challenges in educating SNS, the study has shown that there are issues and challenges related to the teaching career coming from different aspects. Among them, academically and professionally qualified teachers, knowledge about the characteristics of special needs students, confident teachers to present content of Islamic Education (Mohd Mokhtar \& Aliza, 2004, infrastructure of disabled-friendly environment that supports the process of learning Islamic Education (Mohd Hanafi et al., 2009; Norakyairee et al., 2011) and the lack of in-service training. For example, IET issues and challenges in the teaching of the Quran to the SNS with Vision problems centered on IET skills in teaching the Quran aided by Braille Quran, teaching time constraints, no basic knowledge of the Holy Quran for the SNS, no teaching aids, and lack of support from parents (Hajarul Bahti et al., 2010). Same goes to the negative perception of mainstream teachers and school administrators, especially in the Special Education Program Integration (SEPI) which also project a negative impact on the professionalism of teaching Special Education. Obviously, factors of skilled teachers, special children willingness, parents and community awareness and authorities identified as the main factors that con- 
tributed to the void in the Special Education programme. However, according to Zaini et al. (2013), factors of teacher development that can educate with particular care should be given priority in order to achieve the goal of offering the Quran education classes for children with special needs as offered to the typical children throughout the state.

\section{Teacher as Murabbi for Special Education}

One of the roles of IET is based on the five concepts of mim highlighted by Ab. Halim (2006) is to serve as a Murabbi. Murabbi term refers to the role of the teacher in the classroom to maintain, expand, love, educate, teach, nourish and preserve nature and shape students' talents and abilities that exist within them. Teachers serve to realize the formation and development of the students so as to produce JERI aspects of human moral righteousness, in accordance to Islamic perspective.

In this context, the role of teachers as Murabbi not only responsible for educating in the school, but they also serve to improve the condition of society. In other words IET as Murabbi has greater responsibility than an ordinary teacher, because they are the educators at the school, family and community (Salhah Abdullah \& Ainon Mohd, 2007). To achieve these goals, IET as Murabbi have to prepare themselves with a set of personal qualities to be able to successfully implement this trust. Its essence is truly the rabbani thought, religion and practicing the mastery of knowledge, skills in teaching and perfection in character (Abdullah Nasih Elwan, 1968; al-Hafiz al-Suwaid, 1988).

However, in the context of special education and general education of the Qur'an for special children in particular, essence of a Murabbi teacher above should be detailed according to suitability and requirements of this group. This is intended to provide space for these special children to get the right education and ultimately allows teachers to interact and assess their ability through the Murabbi element concept. Therefore, this study outlines the eight (8) elements that can be summarized as a model Murabbi teacher (Special Education):

\subsection{Rabbani Thoughts}

Murabbi teacher character starts from the thought formed in the mind of a teacher who also needs to be Rabbani. This is because thinking is truly the Rabbani thoughts that trigger the character of a teacher. Rabbani thoughts is a terminology taken from the Arabic, al-Tafkir al-Rabbani (Al-Hammadi, 1987). There is also other terminology used to refer to the same thing, which is al-Tafkir al-Ukhrawi (Said, Hawa 1990).

Thinking is the process of using the mind to find meaning and understanding of things, exploring various possibilities idea or invention and sound judgment, to make decisions and solve problems and further reflection and metacognition of experienced process (Jamal Badi \& Mustafa Tajdin, 2005). Rabbani word is derived from the

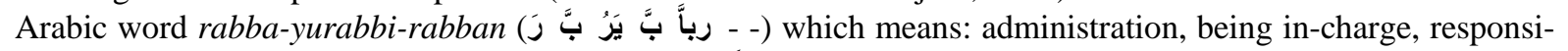

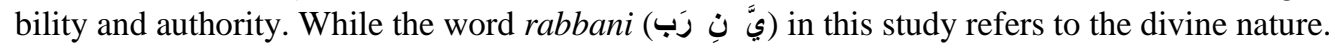

Hence, it can be concluded that rabbani thoughts refers to the process of using the mind to find meaning and understanding of things, exploring various possibilities idea or invention and sound judgment, to make decisions and solve problems and further reflection and metacognition experienced process based on God Almighty (Noornajihan Jaafar \& Noor Zulaili, 2012; Said Hawa, 1990). In other words, a person is said to have rabbani thoughts is one who puts Allah s.w.t blessings and Prophet s.a.w. in the mind that acts as a tool to control the actions both in terms of behavior or speech (al-Baqarah, 2:265).

According to Sidek Baba (2011), rabbani thoughts or soul is vital for educators to reinforce the knowledge presented to students. This is because knowledge itself are truly rabbani thoughts of Allah s.w.t. The most accurate example is of how the Prophet Muhammad received the instruction and upbringing which are truly rabbani thoughts that formed rabbaniyah character. According to Taha Abdullah al-'Afifi (1998) the life of a teacher who has truly the rabbani thoughts across every aspect of life and to teachers who truly possess the rabbani thoughts is formed by the following formula:

1) Spirituality: Doing acts of worship on the concept of honesty and courtesy;

2) Family: Being able to balance between family and career responsibilities;

3) Social: Caring for human relations;

4) Education: Seeing education as a source of trust from God;

5) Career: Looking career as obligation;

6) Property: Using it to Allah's way and 
7) Health: Optimizing good health to find Allah’s blessing.

\subsection{Mastery of Knowledge and Charity}

Mastery of knowledge in the context of this study refers to the concept of knowledge and deed (Ab. Halim et al., 2004; al-Gahazali, 1939; Kamarul Azmi, 2010; Mohammad Shatar et al., 2006) and is a prerequisite in developing character, especially in the aspects of education. This is in line with the call of the Quran on the importance of knowledge as Allah says in Surah al-Isra': 17:36 which means: "Nor should any of you follow whatever that you have no knowledge of, hence hearing, sight and hearts, all will be asked."

Although the issue of knowledge is seen as a normal phenomenon and simple in life, but the debate is a matter of complex and very broad. This is because of differences in knowledge according to Islam and the Western perspective which we find a range of issues and the most obvious is in terms of an intrinsic source of knowledge that separate between science and religion. This separation resulted in chaos and depravity in the Western world known as the dark ages despite the fact that they receive knowledge and philosophy in the map world of knowledge.

Knowledge from the perspective of Islam does not reject the approach proposed by the Western theory based on the Hadith narrated by Imam Tarmizi that says: "Wisdom is something missing from every believer. Wherever he finds it, he is entitled to it”. Wisdom as the debate among Islamic scholars refer to the Quran and Sunnah which is the main reference in the context of knowledge (al-Baqarah 2:269). Encouragement is also carried by Imam Hassan al-Banna in preaching (Motion twenty) to liberate the Islamic state of mind, encourage to observe (study) of the universe, upgrading the position of knowledge and scholars and to welcome something good and beneficial as long as it upholds with the Quran and Sunnah (al-Khatib, 2001). Therefore, the most potent drug for sustainability of knowledge is the concept of charity. This is explained in the Qur'an in a combination of the principles of knowledge and the concept of charity. Allah says in Surah al-'Asr:103:2-3; Meaning: Truly man in losses. Except those who believe and do good works.

In this context, teachers as Murabbi must established the diversity of knowledge and apply them in all his or her actions. Among them;

1) Religious knowledge;

2) Parenting knowledge;

3) Education knowledge (Special Education);

4) Science doctorates (Child Specialists, Eye Specialists, Ear Specialists, etc.);

5) Therapeutic knowledge (Al-Quran and zikir, ways of working and Communications).

\subsection{Positive Personality}

Islamic viewpoint on character is closely related to the human personality and moral behaviour. Development of the human personality in Islam claimed to emphasize the spiritual and physical terms. Imam al-Ghazali (1939) saw the development of personality encompasses all aspects of the individual that involve knowledge of religion, faith, worship, appreciation of the Qur'an, the manners of life, family life, finding means for a living, human relations, morality and character and soul development and heart. Imam al-Nawawi (1983, 2000, 2004) also looks at personality development which embodied in the eight major aspects of character development aspect to God, fellow human moral, social, manners of life, worship, holy, religious knowledge and limitations.

According to Abdullah Nashih 'Ulwan (1968), the character building consists of four elements, namely the construction of the basis of faith, worship, manners and appearance (Mohd Nasir Ripin et al., 2006). Al-Syaibani (1979) summarize the characteristics of the formation of the Muslim personality encompasses the spiritual, moral and the physical aspect. These features are faith-based (spiritual) which is expressed through the supremacy of character (moral) and applied through mental balance, spiritual and physical (physical).

According to Allport (1961) in his book Pattern and Growth in Personality which defines personality as a dynamic organization that determine individual behaviour and thought or known as psychophysical system. The system includes all the psychological elements such as habits, attitudes, values, beliefs and emotions along with the physical elements such as body shape, nerves, glands, and facial gestures of a person (Mok Soon Sang, 1994). According to him, the personality has three main features:

1) Uniqueness in its own meanings;

2) Adaptability or ability to change and be changed as a result of learning and experience, and 
3) Organization, that it is not just a collection of behaviours rather it involves a pattern of actions and operations that are consistent.

Obviously, the character reflects the nature, physical, cognitive, emotional, social and spiritual of a person. In the context of education, teachers' personality will clearly affect the formation of the students' personality, particularly from the point of character through role models (Ab. Halim, 2004; Ab. Halim et al., 2007; Ibrahim Mamat, 1997; Kamarul Azmi, 2010). Sophisticated technology, complete teaching aids and sound pedagogy, all of these cannot replace the role of the teacher as a mediator of knowledge. Hence, the birth of a unique teacher personality through learning and rewarding experience will indirectly shape excellent personality that produce lesson plans and operations effectively and consistently. Among the personality to be highlighted in this context is:

1) Interest and loving new adventure (K. A. Razhiyah, 2010);

2) Patience for disabled students;

3) Paying attention to the needs of disabled students;

4) Respecting difference for disabled students.

\subsection{Educating with Heart}

The heart is the core of the change in thinking and behaviour. Due to the very significant role in human life, the Quran has repeatedly mentions the term heart (qalb) in 132 times. The term heart refers to the basic meaning of the word, which are flipped, back, change or fluctuate. Suitable to the definition, the heart has the ever-changing nature, because the heart is the nucleus of good and evil, right and wrong (Abu Ridhwan, 2011). The heart is something unique, it can be strong, dynamic, and it can feel pain, it can also be blind. Allah says in Surah al-Hajj:22:46.

Meaning: So, Have they not travelled the land so that - to see the effects-they be the ones who have hearts with which to understand, or ears with which to hear? (But even if they travel, and still not too useful) because the actual situation is not the eyes that are blind, but blind are the hearts which are in their breasts. In this context, the approach is to educate the heart with affection born of parenting feelings as Allah says in Surah al-Isra': 17:24;

Meaning: O Lord, love them as they taught me as a child.

This is because the concept of love is amplified with al-Taqwa theory pioneered by Sayyidah Rabi'atul Adawiyah, a Sufi woman who translated her slavery ('Ubudiyyah) to God through the concept of love. According to her, the obligation to do the orders and leave prohibitions of Allah not because of taklif law or fear of the wrath of God, but because of her love to God. In addition, the term educate (Tarbiyyah) also refers to the practice of love, preserve, educate, develop, enrich and enlarge (Tengku Ghani Tengku Jusoh, 2002). This is in line with the recommendations of Imam al-Ghazali, who put a priority in the element of love through the concept teacher as Murabbi:

1) Love the pupils and treat them like their own children;

2) Always advise pupils in all matters including their learning and behaviour, and

3) Maintain discipline using precautionary approach and addressed them good against evil behaviour and foster a loving kindness.

\subsection{Teaching Skills}

Teaching skills is among the basic elements of the Standard Model Malaysian Teachers (MMT). There are three standards in the model that empower profesionlisme of teaching, namely:

1) The professional teaching practices;

2) Knowledge and understanding, and

3) Teaching \& Learning skills.

The term skill in English is referred to as Maharah in Arabic. According to al-Ba'labaki (2003), the term contains a variety of purposes such as skills of agility, efficiency, intelligence and wisdom, knowledge, and expertise. According Gergers (2005), in terms of skills in general education may be defined as the ability to do work that yielded very useful and give satisfaction to the people who assisted as hand skills, painting, and music. In addition to helping to address the problem of how, skill also focus to whatever art or science that led to the achievement of specific goals. This is consistent with the statement that their skills are also affected by the 
adoption of knowledge in guiding students towards the truth.

Skills in the context of the field of special education in general may be defined as the competencies, skills and knowledge of technical man power in the field of operations involving cognitive, psychomotor and effective use of resources (Ahmad, 1997; Zamri, 2007 in Lokman et al., 2009). According to Esah Sulaiman (2003), skills in this context, means the competency, efficiency and knowledge in imparting skills to the students with special needs. As educators, teachers need to master the skills, especially regarding how to educate, nurture and even guiding the SNS to be able to wake up and be one of the contributors to the development of human resources. Skills and teaching techniques as well as compatible with SNS expected to enhance the ability of their interest in the subjects studied. According to Kamarul Azmi (2010), skills simply refers to high ability that do not come to any person other than through experience, continuous self-testing and schooling.

According to Wood, J.W. (2002), teachers who teach Students with Special Needs (SNS) should have the skills to teach the pupils' learning needs by category and specialty of pupils. The matter should be considered by teachers to ensure that pupils with special needs learn more effective and not feel left out and lose interest in learning. In this context, several aspects need to be emphasized in order to achieve learning goals, including:

1) Curriculum appropriate to the ability level of the SNS;

2) Creative and innovative while teaching (Wan Marzuki 2008);

3) Skills to use teaching aids (TA) effectively; and

4) Skills to plan and assess the level of students through the Individual Education Plan (IEP).

\subsection{Effective Communication}

Islam positions communication as an important medium in delivering information. Therefore, Islam clearly outlines the main principles and methods related to effective communication as Allah says in Surah al-Baqarah: $2: 83$.

Meaning: ... and say to the people with good words.

This was approved by Saodah et al. (2005), where research shows that Islam places a number of principles as a guideline, that is to speak softly, to use good words, to use wisdom and good advice, to do what has been said, and taking into account the views of others.

According to Sulaiman Masri (1997), the definition of communication can be formulated as an art exchange or transfer of information in which communication starts when a message (information) from the sender (speaker, writer) is transferred through the device or channel to a receiver (reader, listener) which then provide feedback (encode and interpret) the message.

In this context, apart from the pedagogical and psychological skills, teachers also said to be skilled in teaching communication skills. Communication skills account for a general mention first then specific later, delivering lessons with clear, smooth and compact, insert a word of advice in teaching, create similes and comparisons of teaching, insert narrative elements in teaching, using non-verbal communication, calling students to good call (Kamarul Azmi \& Ab. Halim, 2007). In other words, this communication occurs either oral (verbal) or non-verbal. However, in the context of early childhood education, non-verbal communication such as language materials, posture, sound, and eye-contact are easily understood communication points (Khairul Anuar, 2012). Thus, the teacher as Murabbi in this context should be wise to communicate especially in situations such as below:

1) Communication with disabled students;

2) Communication with parents/guardians;

3) Communication with school administrators;

4) Communication with colleagues.

\subsection{Self Motivation}

In the Islamic perspective, the term motivation in Arabic known as Targheeb which means the rise of individual inclination and desire either love or want or give a loved what (al-Ba'labaki, 2003; al-Bustani, 1956; al-Fayruz Abadi, 1995; Ibn Manzur, 1997). According to Kamarul Azmi (2010), Islamic scholar defines motivation as a stimulus that drives individuals to like doing his job just to earn blessings of God. Islam does not reject the opinion that motivation theory is closely related to human behavior. This is because each person has different needs and life can be summed up into two main requirements for survival needs (physiological) and the need to 
achieve peace of mind (spiritual and physical) (Muhammad Uthman Najat, 2008).

However, the difference between the Western and Islamic motivation theory predicate upon the foundation and source of motivation holding the faith belief that influence values and human behavior. According to Azhar Awang (2004) in Baharom and Iliyas (2011), a strong faith foundation will indirectly shape laws and morals that can increase individual motivation to achieve success, even inhibited by the influence of the current environment. Motivation in Islam can be seen from the point of application through work ethic of Muslims and the motivator is not limited that is love as a superior driver. Among the main benefits of the application of Islamic motivation to other individuals is able to increase the internal resistance themselves, encourage achievement, and guidance to rise from failure to form a positive personality that will always connects to God (Baharom \& Iliyas, 2011; Muhammad Uthman Najat, 2008).

This means that the stimulus caused by motifs factors which is the early acting needs and incentives reward achievement of either intrinsic (internal) or extrinsic (external) capable of linking individual behavior to the orders and prohibitions of Allah SWT. This is in line with the concept of motivation in Islam (Targheeb) which aims to give joy and attract those targeted to receive truth and remain in the truth (Abd al-Karim wrote in 1972). According to Al-Syaikh Ali Mahfuz (1975), the concept Targheeb is meant also as a good promise to those who always maintain the specified limits of Allah s.w.t. which they rumored to news of many favors in this world and hereafter. This approach is used to attract individuals to be more conscientious in obeying Allah s.w.t. and indirectly build excellent character based on practiced knowledge and skills that are always motivated (al-Ghazali, 1939; al-Nahlawi, 2004; Mohammad Shatar et al., 2006).

In the context of this study, teacher is a mirror of student motivation in the construction of the concept of successful pupils that overcome the role of parents and peers (Abdullah \& Ainon, 2011). This is because the motivation affects student behavior and the existence of individual differences among them. According to Ragbir Kaur (2010), individual differences involve differences in religion and culture (spiritual), physical (physical), the wisdom (intellectual), emotional and social. Student differences in the process of teaching and learning in the classroom demand teacher's ability to strive to make their teaching more effective and efficient. Understanding students individual differences have very significant implications for the role of teachers specifically IET SNS in building effective teaching skills. Among the actions that teachers have high motivation in influencing students' personality through this understanding include:

1) Planning more systematic classroom management;

2) Diversify teaching strategies;

3) Using creativity and innovation in T\&L;

4) Divide the students in the group as homogeneous to enable T\&L function effectively;

5) Conducting individual lessons appropriate to teacher-student time, and

6) Having effective communication with parents as early as possible in the survival guide to assist children's education.

\subsection{Continuing Training and Education}

In Malaysia, the existence of the Institute of Teacher Education (IPG) Special Knowledge Campus (ICC) located in Cheras, Kuala Lumpur since 1962 show the Ministry of Education's efforts in creating a competent and spirited teacher educators through a dynamic teacher development program towards a world-class school education (source: http://www.ipik.edu.my).

Special education teachers' professional issues mentioned at the beginning of this study, require the potential development of some teachers who participate in this field unintentionally. Halimah Harun (2006) conducted an interview related to interest, motivation and skills of 25 trainee teachers majoring in Commerce subject from the Faculty of Education to get feedback about the factors that lead them to choose a career in education. The results showed that the process of teacher education and training should determine teacher candidates have the interest, attitude and high motivation of the teaching profession and skills in teaching and learning. In other words, interest, motivation and skills are among the criteria that should be given due attention not only to candidates but also to the teacher education teacher training for planning training courses periodically to strengthening the quality of teachers, especially in the field of Special Education.

Hasnah study et al. (2010) titled Level Training, Knowledge and Confidence of Special Education Teachers On Autism shows that without sufficient training will cause them lack of confidence and are unable to carry out 
their duties effectively. Formal teaching courses available are less effective in the training of special education teachers to understand autism and thus to educate children with autism. The teachers were also found to have low confidence in this field. However, they are keen to undergo further training to increase their efficiency to educate these children.

Thus, the formal teaching courses in the country should be improved by adding specific components according to SNS category. For example, offer related training courses on sign language, Braille Quran teaching, Quran therapy, occupational therapy, communication therapy, and so on. These things can be implemented with the cooperation of any offerings in expertise and training courses either from NGOs, Therapy Center, State Islamic Religious Council, and so on.

\section{Conclusion}

In Malaysia, the policy of the Special Education is stated in the Students Act (1961), namely:

"Special schools mean schools that provide special education services for students with disabilities".

Education Act 1996 also empowers the minister to provide special education facilities, mould an appropriate curriculum, offer education appropriate to the nature of students as well as other measures to expand Special Education. This means, the space and opportunity in supply and improvement in this area is wide open. In other words, if we have already labelled disabled education as a special school education with special treatment, then the special children should get the opportunity and the right of education and assessment that is special and privileged. This should be the same for teachers in this special field. They are also special and should be treated as special.

Therefore, strengthening the teaching profession among IET particularly in the Special Education system should be taken seriously by the various parties. This is aimed at making educational institutions especially Special Education as "domestic" in which the teacher serves to inspire and motivate the students to develop the potential of the SNS. These positive developments eventually lead students to feel proud and have a sense of belonging as stated in "My school My home" concept (Ahmad \& Khalif Muammar, 2005). This indirectly will make teachers see students with positivity and strive to serve them on humanitarian principles. In a positive and friendly atmosphere, the seeds of love and human values will grow lush (Gunasegeran, 2004; Ismail Abbas, 2007; Shea \& Bauer, 1991). Hopefully, as the teacher models Murabbi (Special Education) is able to dedicate, inspire and guide this noble career.

\section{References}

Ab. Halim Tamuri (2011). Penghayatan Islam Melalui Pengajaran dan Pembelajaran. Kongres Pendidikan Islam Kebangsaan. Kuala Lumpur.

Ab. Halim Tamuri dan Mohamad Khairul Azman Ajuhary (2010). Amalan Pengajaran Guru Pendidikan Islam Berkesan Berteraskan konsep al-Mu'allim. Journal of Islamic and Arabic Educcation, 2, 43-56.

Ab. Halim Tamuri dan Zarin Ismail (2006). Model Guru Pendidikan Islam: Konsep 5 Mim. Ppaper presented at Conference of Amalan Pengajaran Guru Pendidikan Islam. Bangi: Universiti Kebangsaan Malaysia.

Abdullah Basmeh (2010). Tafsir Pimpinan al-Rahman. Kuala Lumpur: Dar al-Fikir.

Abdullah Hassan dan Ainon Mohd (2011). Guru Sebagai Pendorong dalam Darjah. Edisi Kemas Kini. Selangor: PTS Professional Publishing Sdn. Bhd.

Abdullah Nasih Alwan (1968). Tarbiyyah al-Awlad fi al-Islam. Kaherah: Dar al-Salam.

Ahmad Mohammad Said dan Khalif Muammar A. Haris (2005). Pembangunan watak bangsa: Pemerkasaan nilai-nilai murni pendidikan. Bangi: Kolej Darul Hikmah.

Ahmad Mohd Salleh (2004). Pendidikan Islam: Falsafah, Sejarah dan Kaedah Pengajaran Pembelajaran. Selangor: Fajar Bakti Sdn. Bhd.

al-Alusi Mahmud ibn Abdullah (2001). Ruh al-Ma'ani fi Tafsir al-Quran al-Azim. Beirut: Dar al-Kutub al-Ilmiyyah. al-Ba'labaki, R. (2003). al-Mawrid: Qamus 'Arabiy-Injliziy. Beirut: Dar al-’Ilm li al-Malayin.

al-Bustani, Fu'ad Afram (1956). Munjid al-Tullab. Juz 1-2. Beirut: Dar al-Masyriq.

al-Ghazali, Abu Hamid Muhammad Muhammad (1939). Ihya' 'Ulum al-Din. Mesir: Matba'ah Mustafa al-Bab al-Halabi.

Allport, G. W. (1997). Partern and Growth in Personality. New York: Rinehart and Winston.

Edy, C. (2009). Profil Guru Sebagai Murabbi. http://newuke8554.blogspot.com 
Hajarul Bahti Zakaria \& Mohd Huzairi Awang (2010). Isu dan Cabaran Guru dalam Pendidikan al-Quran Pelajar Bermasalah Penglihatan. Seminar Pendidikan Guru Peringkat Antarabangsa kali ke-4 (UPI \& UPSI). Bandung: Indonesia.

Halimah Harun (2006). Minat, Motivasi dan Kemahiran Mengajar Guru Pelatih. Jurnal Pendidikan, 31, 83-96.

Hasnah Toran, Mohd. Hanafi Mohd. Yasin, Mohd. Mokhtar Tahar \& Norani Salleh (2010). Tahap Latihan, Pengetahuan dan Keyakinan Guru-guru Pendidikan Khas Tentang Autisme. Jurnal Pendidikan Malaysia, 35, 19-26. Bangi: Universiti Kebangsaan Malaysia.

Ismail Abas (2007). Peranan Guru Membina Murid Menghadapi Cabaran Wawasan 2020. Jurnal Penyelidikan Pendidikan Institut Perguruan Islam, 10, 82-89.

Jamila K.A. Mohamed (2005). Pendidikan Khas Untuk Kanak-kanak Istimewa. Pahang: PTS Professional.

Mohd Huzairi bin Awang @ Husain (2010). Peranan Masjid Dalam Pendidikan: Tumpuan Khusus Terhadap Golongan Pekak. Seminar Kebangsaan Pengajaran dan Pembelajaran di Masjid. Shah Alam.

Norakyairee Mohd Raus \& Ab. Halim Tamuri (2011). Program Tilawah al-Quran di Masjid Bagi Golongan Bermasalah Penglihatan: Realiti dan Cabaran Semasa. Seminar Pengurusan Masjid Inovatif Peringkat Antarabangsa, 23-25 April 2011. IAIN ar-Raniry, Banda Aceh, Aceh.

Norakyairee Mohd Raus, Ab. Halim Tamuri, dan Norshidah Mohamed Salleh (2012). Pengajaran Al-Quran Braille: Penglibatan Institusi Pengajian Tinggi Islam Di Malaysia. Seminar Serantau Institusi Pengajian Tinggi Islam. Nilai: USIM.

Norakyairee Mohd Raus, Ab. Halim Tamuri, dan Norshidah Mohamed Salleh (2012). Asas Kesediaan Pengajaran Guru Berkesan dalam Modul al-Quran Berbantukan al-Quran Braille. The International Conference on Research in Islamic and Arabic Language Education 2012 (ICRIALE2012). Saudi Arabia: Mekah.

Norakyairee Mohd Raus, Ab. Halim Tamuri, dan Norshidah Mohamed Salleh (2012). Asas Kesediaan Pengajaran Guru Berkesan Dalam Program Pendidikan Khas Masalah Penglihatan Berdasarkan Konsep al-Rasul al-Mu’allim. Seminar Warisan Nabawi (SWAN2012). Nilai: USIM.

Shea, T.M., \& dan Bauer, A.M. (1991). Parents and Teachers of Children with Exceptionalities. Massachusetts: Allyn and Bacon.

Wan Sabri Wan Husin, Mohd Zaini Mat Abas, Nor’Aziah Mohd Daud, Norakyairee Mohd Raus, Nazean Jomhari, \& Afifah Salleh (2013) Model Pembangunan Institusi Pendidikan al-Quran Bagi Anak Istimewa. The 3rd Annual International Qur'anic Conference, Centre of Quranic Research (CQR), 13-14 March 2013, Universiti Malaya. 